Amir KRPIĆ

Filozofski fakultet Univerziteta u Tuzli

E-mail: krpic.amir@gmail.com

Stručni rad/Professional article

UDK/UDC:94:323.1(4-12)“1790/1918“"Hadžić S. Velagić A. (049.3)

\title{
Senaid Hadžić, Adnan Velagić, BALKANSKA PRASKOZORJA: OD IDEJĀ DO UJEDINJENĀ. JUGOISTOČNA EVROPA U „DUGOM“ 19. STOLJEĆU (1790-1918), Mostar 2019, 490 str.
} (1790-1918), čiji su autori istaknuti historičari prof. $\mathrm{dr}$. Senaid Hadžić i prof. dr. Adnan Velagić. Izdavač knjige je Arhiv Hercegovačko-neretvanskog kantona Mostar, a recenzenti su prof. dr. Adnan Jahić i prof. dr. Denis Bećirović.

Kako se iz naslova može vidjeti, knjiga govori o zemljama i narodima jugoistočne Evrope u vremenu buđenja nacionalne svijesti i izgradnje nacionalnih država, odnosno tzv. dugom 19. stoljeću. Napisana je na osnovu arhivske građe, literature, časopisa i štampe. Autori su koristili neobjavljenu arhivsku građu Arhiva Bosne i Hercegovine u Sarajevu, Arhiva

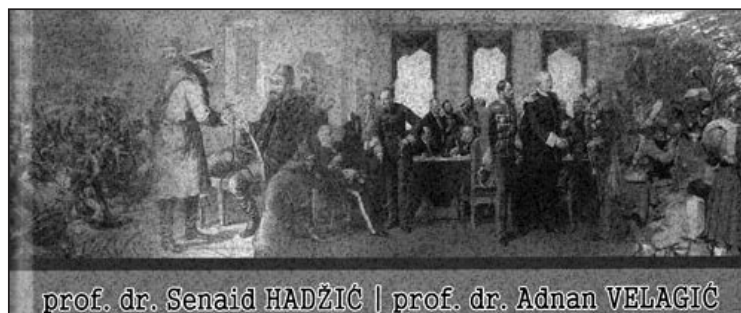

BALKANSKA PRASKOZORJA od idejā do ujedinjenja

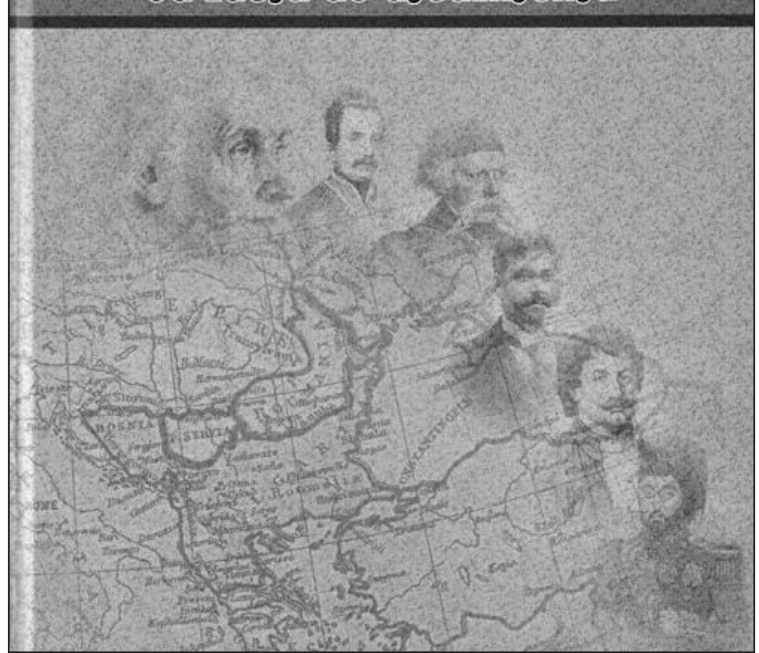
Srbije, Državnog arhiva Srbije u Beogradu i Hrvatskog državnog arhiva u Zagrebu, zatim četrdeset jedinica objavljenih izvora, jedanaest rukopisa, 428 knjiga i studija, 
veći broj članaka i rasprava, te savremene novine i listove iz Sarajeva, Zagreba, Osijeka, Beograda i Novog Sada.

Knjiga je opširna po sadržaju, vremenu i prostoru koji obuhvata, tako da su autori hronološki podijelili poglavlja. Uvodno poglavlje govori o geohistorijskom i geopolitičkom određenju Jugoistočne Evrope u 19. stoljeću, gdje autori iznose stajališta o sličnosti i različitosti pojmova Jugoistočna Evropa i Balkan, te donose zaključak da se ne radi o sinonimima i da svaki pojam ima zasebno značenje. Ovdje još govore o uvodnim napomenama važnim za razumijevanje daljnjih događaja i procesa, objašnjavajući antagonizme u ovoj regiji naslijeđene iz prethodnog perioda. S obzirom na karakter regije, neizbježno je bilo navesti i neke napomene o vjerskoj, etničkoj i kulturnoj raznolikosti, kao i o različitim vladajućim državama u regiji i različitim uticajima koji su se na ovom prostoru preklapali i miješali, ostavljajući na taj način i kulturno i civilizacijski mješovito područje.

Evropska tranzicija u vremenu odumiranja ideala $i$ razvoja nacionalnih pokreta je poglavlje s kojim autori započinju s predstavljanjem historije zemalja i naroda Jugoistočne Evrope u naznačenom periodu. Ovo poglavlje vremenski se proteže negdje do tridesetih godina 19. stoljeća, zavisno od zemlje do zemlje. Počinjući sa Austrijom u vremenu Napoleonovih ratova, autori su najprije predstavili slovenačke i hrvatske zemlje na prelazu iz 18. u 19. stoljeće, opisujući uticaj tadašnjih krupnih evropskih događaja i procesa na slovenački i hrvatski prostor, koji su tome bili naizloženiji, budući da su pripadali Habzburškoj monarhiji, odnosno od 1804. godine Austriji. Autori su ispratili evropska dešavanja i neizbježno se dotakli Bečkog kongresa kao osnove međunarodnih odnosa i društveno-političkih kretanja postnapoleonske Evrope. Također, u ovom poglavlju autori su obuhvatili i period hrvatske historije u tzv. predilirsko doba i ozbiljne pokušaje mađarskih državnika da izvrše što veću integraciju hrvatskih zemalja Mađarskoj.

Objašnjavajući uticaj ideja Francuske revolucije na razvoj zemalja i naroda u Jugoistočnoj Evropi, autori su dalje predstavili onaj istočniji dio ove regije. Osmansko carstvo obuhvaćeno je u vrijeme sultana Selima III i Mahmuda II, tj. u vrijeme pokušaja provođenja korjenitih reformi. Srbija je predstavljena u kontekstu borbe za samostalnost i sticanja autonomije, a Rumunija kao politički razbijen prostor na kojem su se takmičili ruski, francuski i osmanski uticaji, ali i kao područje iznimno važno za proces osamostaljenja još jedne zemlje - Grčke. Slično kao sa Srbijom, i Grčka je obuhvaćena u periodu borbe za nezavisnost. Konačno, predstavljen je i Bosanski ejalet na ulasku u 19. stoljeće.

Drugo poglavlje se hronološki nastavlja na prvo i obuhvata sredinu 19. stoljeća - od tridesetih do sedamdesetih godina. To je veoma sadržajno razdoblje izgradnje i učvršćivanja nacionalne svijesti i početka stvaranja nacionalnih i velikodržavnih projekata, što je bio proces koji je faktički obilježio Jugoistočnu Evropu u drugoj polovini 19. i početkom 20. stoljeća. Autori su najprije predstavili hrvatske i slovenačke zemlje pod austrijskom vlašću, njihove nacionalno-političke 
težnje, ali i težnje drugih slavenskih naroda Austrije, podijeljene na dva nacionalnopolitička koncepta: panslavizam i austroslavizam. Potom su se osvrnuli na jedan od najvećih događaja 19. stoljeća - revolucije 1848/49. godine, te objasnili njihov uticaj na daljnji razvoj hrvatskog i slovenačkog naroda i njihovih prostora.

Osmanske reformske procese nastavili su predstavljati obuhvatajući vladavinu Abdulmedžida I, vladara koji je javno obznanio namjere za reformisanjem osmanskog društva i države prema načelima naslijeđenim od prethodnih reformatora. Potom su autori objasnili i početak nacionalnog i političkog ujedinjenja Rumunije, odnosno tadašnjih kneževina Vlaške i Moldavije, koje su u ovom periodu dobile autonomne statuse. Nakon toga dolazi predstavljanje razvoja Srbije pod vladavinom Miloša Obrenovića i kasnije Ustavobranitelja. Konstituisanje Grčke kao kraljevine i vladavina kralja Otta predstavljeni su u dijelu poglavlja koji se odnosi na Grčku i njene prije svega unutrašnje probleme vezane za prisustvo različitih stranih uticaja i posljedično različitih društvenih i političkih struja u zemlji. Poglavlje se završava predstavljanjem bosanskih pitanja u kontekstu najave provođenja reformi u ovoj osmanskoj provinciji, otpora reformama i njegovom konačnom slomu, te pacifikaciji zemlje i stvaranju preduslova za provođenje planiranih reformi.

U trećem poglavlju autori su pažnju posvetili nacionalnim programima i velikodržavnim projektima koji su nastali sredinom 19. stoljeća kod naroda Jugoistočne Evrope, ali i susjednih srednjoevropskih naroda. Autori su najprije predstavili program Adama Czartoryskog o preuređenju Srednje Evrope na federalnoj osnovi i njegov uticaj na druge projekte u neposrednom susjedstvu. Potom su nešto opširnije objasnili tadašnji program vanjske politike Srbije, odnosno velikosrpski nacionalni projekat Načertanije, a zatim i mađarski nacionalni program prema zemljama i narodima Jugoistočne Evrope, te državni projekat Velike Mađarske. Osim njih, autori su predstavili i grčki nacionalni program, tzv. Velika ideja, ulogu Vuka Karadžića i Ilije Garašanina u stvaranju srpskog nacionalnog programa, te koncept velikohrvatskog programa nakon njegovog preobražaja iz ilirske ideje. Predstavljanjem svih ovih ideja, programa i projekata autori su željeli istaći koliko su nacionalni programi bili značajni za razvoj zemalja i naroda Jugoistočne Evrope u 19. stoljeću, budući da su nacionalne politike bile oblikovane upravo u onom pravcu u koji su ih usmjerili programi i projekti.

Četvrto poglavlje donosi nastavak društveno-političkog razvoja zemalja i naroda Jugoistočne Evrope u narednoj fazi, tj, od pedesetih godina do Berlinskog kongresa. Tako se između ostalog predstavlja položaj hrvatskih i slovenačkih zemalja u kontekstu unutrašnjeg preuređenja Austrijskog carstva u Austro-Ugarsku, te pogledi i zahtjevi drugih naroda Monarhije nakon austrijsko-mađarske Nagodbe 1867. godine. Poglavlje donosi i nastavak provođenja reformi u Osmanskom carstvu, obuhvatajući donošenje prvog osmanskog ustava i otvaranje tzv. prvog ustavnog perioda, te njegov kraj i povratak apsolutizma u vrijeme Velike istočne krize. Autori su također ovdje donijeli i početak izgradnje Bugarske prateći razvoj 
njihove kulturne borbe od kraja 18. stoljeća do sticanja crkvene autonomije u vidu Bugarskog egzarhata. Dalje je obuhvaćen period grčke historije u vrijeme vladavine kralja Georgiosa I, koji pokriva najveći dio druge polovine 19. stoljeća. Tu su autori, vraćajući se na grčki nacionalni program, ponovo istakli važnost nacionalne ideologije u oblikovanju ne samo vanjske politike, nego i svijesti jednog naroda. Također, ukazali su na uticaje stranih sila koji su bili prisutni u Grčkoj, tj. istih onih sila koje su de facto omogućile stvaranje grčke države dvadesetih i tridesetih godina 19. stoljeća. Zbog prisustva tih uticaja, razumljivo je da je grčko društvo bilo podijeljeno, što su autori na jednostavan način ovdje objasnili.

Dalje se u poglavlju prati razvoj Srbije pod dinastijom Obrenovića na njenom putu od autonomije do nezavisnosti, koju je stekla nakon Velike istočne krize. Ponovo u kontekstu nacionalnih programa istaknute su pojačane aktivnosti Srbije, naročito u vrijeme kneza Mihaila Obrenovića, na planu realizacije Načertanija. Nacionalne teme dominirale su i u kneževinama Vlaškoj i Moldaviji, čije su političko ujedinjenje, sa kojim je počela rumunska nacionalna integracija, autori predstavili u podnaslovu posvećenom ovoj zemlji. I ovdje je istaknuta uloga stranog faktora, posebno Francuske, u udaljavanju pokrajina od Osmanskog carstva i stvaranju nove države, čija je nezavisnost priznata i potvrđena na Berlinskom kongresu. Autori su i u ovom poglavlju posebnu pažnju posvetili Bosni u periodu uprave Šerif Osman-paše i posljednjim godinama osmanske vlasti. Detaljno su predstavljene reforme koje su provedene u Bosanskom ejaletu u tzv. zlatno doba, te je objašnjen njihov uticaj na dešavanja koja su ubrzo nakon toga uslijedila. Budući da ovo poglavlje završava sa Berlinskim kongresom, kao događajem od iznimne važnosti za Jugoistočnu Evropu, autori su poseban podnaslov posvetili upravo tome, tj. završetku Velike istočne krize i mirovnim ugovorima iz San Stefana i Berlina. Ovdje su ukazali na značaj ovih događaja za daljnji razvoj kako pojedinih zemalja, tako i regije u cjelini.

Naredno, peto poglavlje obuhvata period od Berlinskog kongresa do početka Prvog svjetskog rata. Autori su najprije ukazali na promjenu austrijske vanjske politike nakon burnih događaja šezdesetih i sedamdesetih godina 19 . stoljeća prema Jugoistočnoj Evropi, ali i na pojavu novih faktora u regiji, prije svega novoizrastajuće sile tog vremena - tek ujedinjene Njemačke. Također su predstavili unutrašnje političke sukobe unutar Monarhije, koji su sve više odražavali etničku podijeljenost i sve ozbiljnije ukazivali na mogućnost njenog novog preuređenja na temelju nacionalnosti i političkih stremljenja. Prodor srednjoevropskog uticaja u regiju neizbježno je bilo zaokružiti njegovim najboljim pokazateljem austrougarskom aneksijom do tada okupirane Bosne i Hercegovine. To je bio veoma važan događaj koji je zapalio balkansko bure baruta, o kojem autori govore u jednom podnaslovu, objašnjavajući preobražaj balkanskih društava u okolnostima sazrijevanja nacionalnih identiteta i izgradnje modernih nacija, smještajući sve to u odgovarajući historijski kontekst. Posebno je obrađen i predstavljen položaj žena u društvima u Jugoistočnoj Evropi u kontekstu pojave i sazrijevanja svijesti o 
pravima žena. Istaknuti su najznamenitiji pojedinci i udruženja i njihove aktivnosti na polju borbe za ravnopravnost spolova.

Potom je nastavljeno predstavljanje društveno-političke historije $u$ Srbiji, Rumuniji, Bugarskoj, Osmanskom carstvu i Grčkoj, ali su u ovo poglavlje uključene i Crna Gora, Albanija i Makedonija, o kojima se ranije nije posebno govorilo. U Srbiji je obuhvaćena dinastička promjena praćena vanjskopolitičkom preorjentacijom sa austrofilstva, kako su to autori označili, na prorusku politiku. Ispraćen je nastavak nacionalne integracije rumunskog naroda nakon sticanja nezavisnosti na Berlinskom kongresu, krunisan uzdizanjem države u rang kraljevstva. Također je ukazano, kao i za druge zemlje i narode, na unutrašnja politička neslaganja koja su se, čini se, neizbježno pojavljivala u tek izrastajućim modernim društvima. Autori su potom objasnili i bugarsku nacionalnu integraciju i put prema nezavisnosti, koji je u ovoj zemlji bio je nešto sporiji, budući da je Bugarska na Berlinskom kongresu tek dobila autonomiju, ali ne i nezavisnost. Zbog takvog statusa, autori su ukazali na posebno pitanje odnosa Bugarske, nakon ujedinjenja sa Istočnom Rumelijom, sa susjednim, tada već nezavisnim državama, jer su među njima postojala još uvijek neriješena pitanja. Unutrašnja politička neslaganja, u ovom periodu možda još i izraženija nego ranije, postojala su i u Grčkoj, što su autori objasnili u zasebnom podnaslovu posvećenom ovoj zemlji.

Uticaj nacionalnih ideja u ovom periodu već se odrazio i na Osmansko carstvo, gdje se također počinju javljati intelektualci i pokreti s vlastitim nacionalno-političkim pogledima. Riječ je o mladoturskom pokretu, koji je na neki način nadgradio raniji mladoosmanski pokret i prije svega bio namijenjen pripadnicima turskog naroda. Autori su pojasnili njegove principe i njihov uticaj na daljnji politički razvoj Osmanske države. Još jedan narod koji je iskusio djelovanje nacionalnih ideja bili su Albanci, čiji su pokret za nezavisnost u jeku Velike istočne krize autori također predstavili i objasnili. Isto važi i za makedonski narod, koji je početkom 20. stoljeća među posljednjima pokazao svoje nacionalno-političke ciljeve u događaju poznatom kao Ilindenski ustanak. Osim ustanka, autori su rasvijetlili i na jednostavan način predstavili cjelokupno makedonsko pitanje, koje je u ovom periodu zaokupilo pažnju susjednih država. Autori su također istakli i posljedice neuspjeha Ilindenskog ustanka na daljnji razvoj makedonskog prostora i naroda. Dalje je prikazan društveni i državno-politički razvoj Crne Gore u jednom dužem periodu, od Petra I Petrovića do kralja Nikole, gdje su istaknuti najvažniji momenti u razvoju Crne Gore kao države. Na kraju ovog poglavlja, autori su hronološki predstavili Balkanske ratove kao posljedicu višedecenijskih nacionalnopolitičkih stremljenja, s jedne strane, te kao uvod u Prvi svjetski rat s druge strane.

Naredno poglavlje posvećeno je zemljama Jugoistočne Evrope u Prvom svjetskom ratu. Autori su dali presjek šireg ratnog stanja u Evropi s fokusom na Njemačku i Austro-Ugarsku, a potom predstavili svaku zemlju Jugoistočne Evrope pojedinačno, podijelivši ih prema njihovoj pripadnosti tadašnjim vojno-političkim savezima. Na kraju su donijeli rezultate mirovnih ugovora koji su se odnosili na 
zemlje Jugoistočne Evrope, te posebno različita načela uređenja postratnih društava. $\mathrm{Na}$ završnim stranicama knjige nalaze se zaključna razmatranja, popis izvora i literature korištenih prilikom pisanja knjige, registar ličnih imena i autora, te izvodi iz recenzija.

Kao što se može vidjeti samim pogledom na sadržaj, knjiga je veoma obimna i bogata podacima i zaključcima važnim za razumijevanje historijskih razvoja naroda i država u Jugoistočnoj Evropi. Istovremeno, s obzirom na sadržaj, knjiga je sažeta, tako da se može reći da ona predstavlja veoma dobru osnovu za dublja historijska istraživanja i proučavanja historije navedenih naroda i zemalja pojedinačno. Drugim riječima, može se reći da su autori u ovoj knjizi na jednom mjestu komparativno predstavili najvažnije informacije o historiji naroda i zemalja Jugoistočne Europe od Francuske revolucije do Versajskog mira. Svima onima koji se interesuju za ovaj veoma buran i sadržajan historijski period, svima onima koji žele više naučiti i bolje razumjeti ne samo tadašnje, već i današnje odnose u Jugoistočnoj Evropi i svima ostalim koji su u mogućnosti, iskreno preporučujem da pročitaju ovu knjigu. 